\title{
Microbial Metabolism of Alicyclic Hydrocarbons. Growth of Nocardia petroleophila (NCIB9438) on Methylcyclohexane
}

\author{
By G. M. TONGE AND I. J. HIGGINS \\ Biological Laboratory, University of Kent, Canterbury CT2 $7 \mathrm{NJ}$, Kent
}

(Received 8 November 1973)

INTRODUCTION

The microbial degradation of benzene and toluene has been described in detail (Kitagawa, I956; Claus \& Walker, 1964; Gibson, Koch \& Kallio, 1968) and in particular the initial oxidative attack on these molecules has been studied more recently (Gibson, Cardini, Maseles \& Kallio, 1970; Gibson, Hensley, Yoshioka \& Mabry, 1970). There is, however, little information concerning the degradation of the alicyclic analogues, cyclohexane and methylcyclohexane. Unidentified soil isolates can grow on methylcyclohexane as sole carbon and energy source (Fredericks, I966), and another soil isolate, though unable to utilize this hydrocarbon for growth, co-oxidizes it to a ketonic product tentatively identified as 4-methylcyclohexanone (Ooyama \& Foster, 1965). There is evidence that soil microbes can oxidize cyclohexane (Jones \& Edington, I968) and that the mechanism probably involves co-oxidation (Beam \& Perry, 1973).

This communication describes the growth of Nocardia petroleophila on methylcyclohexane as sole carbon and energy source and the identification of catabolites that transiently accumulate in the culture medium.

\section{METHODS}

Micro-organism, source, maintenance and culture. Nocardia petroleophila (NCIB9438) was maintained on nutrient agar slopes $\left(2.8 \%, \mathrm{w} / \mathrm{v}\right.$, Oxoid $\left.\mathrm{CM}_{3}\right)$ and was grown routinely at $30{ }^{\circ} \mathrm{C}$ in liquid culture in magnetically-stirred fermenter vessels (I 1 capacity) or in impelleragitated fermenter vessels ( 5 and $\mathrm{I} 61$ capacity). Aeration was $0 \cdot \mathrm{I}$ vol. of air/vol. of culture medium $/ \mathrm{min}$, and methylcyclohexane $(0.5 \%$ or $\mathrm{I} \%, \mathrm{v} / \mathrm{v})$ was added to a mineral salts medium (Davis \& Raymond, 196I) containing I ml trace metal mixture/l (Bauchop \& Elsden, 1960).

Measurement of growth. Growth was measured by a modification of the method of Manfredi \& Wang (1972). Samples were mixed with 3 vol. of propionic acid to emulsify the hydrocarbon and aqueous layers. After $15 \mathrm{~min}$ at room temperature, $E_{630}$ was measured and related to dry weight of organisms by a standard curve prepared by using washed suspensions containing methylcyclohexane.

Preparation of washed suspensions of bacteria. Organisms were harvested by centrifuging ( $23000 \mathrm{~g}, \mathrm{I} 5 \mathrm{~min}, 25^{\circ} \mathrm{C}$ ), washed twice with ro mM-sodium phosphate buffer, $\mathrm{pH} 7 \cdot 0$, and resuspended in the same buffer.

Measurement of oxygen uptake. Oxygen consumption was measured at $30{ }^{\circ} \mathrm{C}$ using an oxygen electrode (Rank Bros., Bottisham, Cambridge). Incubation mixtures contained sodium phosphate buffer $(20 \mu \mathrm{mol})$, substrate $(300 \mu \mathrm{mol})$ and bacterial suspension (9 to I $8 \mathrm{mg}$ dry wt) in $3.0 \mathrm{ml}$.

Extraction and analysis of culture supernatants. Organisms were harvested by centrifuging 
Table I. Mass spectra of methylcyclohexane metabolites formed by Nocardia petroleophila NCIB9438 compared with those of authentic samples of methylcyclohexanol and methylcyclohexanone isomers

\begin{tabular}{|c|c|c|c|c|}
\hline \multirow[b]{2}{*}{$m / e$} & \multicolumn{4}{|c|}{$\begin{array}{c}\text { Abundance relative to the base peak of compound } \mathrm{A} \text { for } \\
\text { major fragmentation ions }\end{array}$} \\
\hline & Compound $\mathbf{A}$ & $\begin{array}{l}\text { 2-Methylcyclo- } \\
\text { hexanol }\end{array}$ & $\begin{array}{l}\text { 3-Methylcyclo- } \\
\text { hexanol }\end{array}$ & $\begin{array}{l}\text { 4-Methylcyclo- } \\
\text { hexanol }\end{array}$ \\
\hline I I 4 & 0.051 & 0.33 & 0.042 & 0.80 \\
\hline 96 & 0.80 & $I \cdot 34$ & 0.80 & $4 \cdot 00$ \\
\hline 81 & 0.65 & $I \cdot 40$ & 0.70 & $4 \cdot 75$ \\
\hline $7 \mathrm{I}$ & $1 \cdot 00$ & $I \cdot 00$ & $I \cdot 00$ & $1 \cdot 00$ \\
\hline 57 & 0.38 & 0.26 & 0.40 & $7 \cdot 70$ \\
\hline & \multicolumn{4}{|c|}{$\begin{array}{l}\text { Abundance relative to the base peak of compound } \mathbf{B} \text { for } \\
\text { major fragmentation ions }\end{array}$} \\
\hline$m / e$ & Compound $\mathrm{B}$ & $\begin{array}{l}\text { 2-Methylcyclo- } \\
\text { hexanone }\end{array}$ & $\begin{array}{l}\text { 3-Methylcyclo- } \\
\text { hexanone }\end{array}$ & $\begin{array}{l}\text { 4-Methylcyclo- } \\
\text { hexanone }\end{array}$ \\
\hline II 2 & 0.40 & $I \cdot 54$ & 0.41 & $2 \cdot 18$ \\
\hline 97 & 0.16 & 0.34 & 0.17 & $0.4 \mathrm{I}$ \\
\hline 69 & $I \cdot \infty$ & $I \cdot 00$ & $I \cdot 00$ & $\mathrm{I} \cdot 00$ \\
\hline 68 & 0.10 & $2 \cdot 27$ & $0 \cdot 10$ & 0.88 \\
\hline 56 & 0.39 & $I \cdot I 4$ & 0.40 & $2 \cdot 18$ \\
\hline 55 & 0.15 & 0.77 & 0.17 & 5.90 \\
\hline
\end{tabular}

The extraction of compounds A and B from culture supernatants and subsequent combined gas liquid chromatography-mass spectrometry are described in Methods.

as above and samples of culture supernatant $(50 \mathrm{ml})$ were then extracted rapidly, without shaking, with an equal volume of diethyl ether to remove the remaining hydrocarbon. The remaining aqueous fractions were evaporated to approximately $0.5 \mathrm{ml}$ with a rotary evaporator under reduced pressure at $60{ }^{\circ} \mathrm{C}$. The residues were taken up in methanol $(2.5 \mathrm{ml})$ and subjected to gas liquid chromatography using two prepacked coiled glass columns $(\mathbf{I} \cdot 83 \mathrm{~m} \times$ $2.0 \mathrm{~mm}$ internal diameter), one containing 3\% methylsilicone gum (SE 30) on 100 to I 20 mesh Gas Chrome Q, the other $10 \%$ Apiezon L on 100 to I 20 mesh Diatomite C (Pye Unicam Ltd, Cambridge). A Pye model 104 gas chromatograph fitted with a flame ionization detector was used and operating conditions were: carrier gas $\left(\mathrm{N}_{2}\right)$ at $40 \mathrm{ml} / \mathrm{min}$, oven temperature 180 to $200{ }^{\circ} \mathrm{C}$, and detector temperature $225^{\circ} \mathrm{C}$.

Gas liquid chromatography-mass spectrometry. The mass spectrometer used was an AEI MS 30 (Associated Electrical Industries) and separation was effected by gas chromatography on $10 \%$ Apiezon $\mathrm{L}$ under the conditions described above using $\mathrm{He}$ as carrier gas.

Chemicals. Methylcyclohexane was obtained from BDH Ltd, Poole, Dorset, and contained some cyclohexane $(\mathrm{I} \cdot 8 \%, \mathrm{v} / \mathrm{v})$ and unidentified components $(0 \cdot 2 \%, \mathrm{v} / \mathrm{v}) ; 2-, 3-$ and 4-methylcyclohexanol and 2- 3- and 4-methylcyclohexanone were purchased from Eastman Kodak Ltd, Kirby, Liverpool. All other chemicals were of the highest grade available commercially.

\section{RESULTS}

Growth studies

For optimum growth of Nocardia petroleophila on methylcyclohexane, organisms were initially grown on nutrient broth $(0.8 \% \mathrm{w} / \mathrm{v}$, Difco), harvested during exponential growth, 
washed aseptically, and resuspended in sterile sodium phosphate buffer (10 $\mathrm{mm}, \mathrm{pH} 7 \cdot 0$ ) which was then inoculated into mineral salts medium containing hydrocarbon $(0.2 \mathrm{~g}$ dry wt of organisms/1 medium). Yields of up to $0.75 \mathrm{~g}$ dry wt of organisms/g of methylcyclohexane were recorded though growth was slow (mean generation time approx. $40 \mathrm{~h}$ at $30^{\circ} \mathrm{C}$ ).

\section{Identification of methylcyclohexane metabolites in the culture medium}

Residues from exponential phase culture supernatants, dissolved in methanol, reacted with 2,4-dinitrophenylhydrazine indicating the presence of a carbonyl compound. Gas liquid chromatography of these residues on methylsilicone gum ( $\mathrm{SE} 30$ ) at $180^{\circ} \mathrm{C}$ showed two overlapping peaks with retention times of $2 \cdot 0$ and $2 \cdot 3$ min respectively. All isomers of methylcyclohexanol and methylcyclohexanone have retention times of between $2 \cdot 0$ and $2.3 \mathrm{~min}$. Retention times for the two components on $10 \%$ Apiezon L at $200{ }^{\circ} \mathrm{C}$ were 1.5 and 2.9 min respectively, whilst those for $2-, 3$ - and 4-methylcyclohexanol were $2.4,1.5$ and $2.3 \mathrm{~min}$ respectively and for $2-, 3$ - and 4 -methylcyclohexanone were $3.0,2.9$ and $3.2 \mathrm{~min}$ respectively. This data was consistent with the two unknown compounds, A and B, being 3-methylcyclohexanol and 3-methylcyclohexanone. Mass spectra, obtained by combined gas chromatography-mass spectrometry, of these two isolated compounds and authentic compounds were the same (Table I). Mass spectra of the other isomers were clearly different.

The absence of these compounds from stationary-phase culture supernatants suggests that they are further utilized by the micro-organism. The maximum concentrations (uncorrected for extraction losses) of 3-methylcyclohexanol and 3-methylcyclohexanone detected in exponential phase cultures were $\mathrm{I} \cdot 6$ and $\mathrm{I} \cdot 0 \mathrm{mM}$ respectively. However, upon adding either sodium arsenite $(5 \mathrm{mM})$ or 2,4 -dinitrophenol $(5 \mathrm{mM})$ to growing cultures $60 \mathrm{~h}$ after inoculation into methylcyclohexane medium, these amounts increased to 18 and $9 \mathrm{~mm}$ respectively. Addition of inhibitor rapidly and completely inhibited growth, accumulation of the alcohol and ketone occurred over the following 20 to $30 \mathrm{~h}$ and they were not further utilized.

\section{Polarographic studies}

Washed suspensions, prepared from exponential phase organisms growing on methylcyclohexane, oxidized methylcyclohexane, 3-methylcyclohexanol and 3-methylcyclohexanone at rates of 30,57 and $60 \mathrm{nmol} \mathrm{O}_{2}$ utilized $/ \mathrm{mg}$ dry $\mathrm{wt} / \mathrm{h}$ respectively. These values have been corrected for the endogenous rate which was $26 \mathrm{nmol} \mathrm{O}_{2}$ utilized/mg dry wt/h. The remaining isomers of methylcyclohexanol and methylcyclohexanone did not stimulate oxygen uptake above the endogenous level.

\section{DISCUSSION}

The results demonstrate that Nocardia petroleophila (NCIB9438) possesses the unusual capability of growth on an alicyclic hydrocarbon as the sole carbon and energy source, and the high yields indicate efficient utilization of the hydrocarbon. The detection of 3-methylcyclohexanol and 3-methylcyclohexanone in the culture medium during exponential growth and the increase in their concentrations resulting from addition of inhibitors suggest that these compounds are intermediates in methylcyclohexane catabolism. This hypothesis is further supported by the ability of washed suspensions to oxidize these compounds and their inability to oxidize the other isomers. Although the absolute rates are low, they represent approximately twice the rate obtained for methylcyclohexane. These compounds have not been detected previously as microbial catabolites and their identification indicates that 
the initial step in methylcyclohexane degradation may be oxygenation to form 3-methylcyclohexanol followed by dehydrogenation to form the ketone, 3-methylcyclohexanone. The latter step would be analogous to the initial reaction in cyclohexanol degradation by Acinetobacter NCIB987I (Norris \& Trudgill, 197I) and probably by Nocardia globerula (Norris \& Trudgill, 1971). Confirmation that these compounds are bona fide intermediates awaits the detection of the appropriate enzymes in cell-free systems.

We wish to thank Mr D. Green of Shell Research Ltd, Sittingbourne, for combined gas liquid chromatography-mass spectrometry. This work was supported by a research grant from the SRC to I. J. H.

\section{REFERENCES}

Bauchop, T. \& ElsDen, S. R. (1960). The growth of micro-organisms in relation to their energy supply. Journal of General Microbiology 23, 457-470.

Beam, H. W. \& PeRry, J. J. (1973). Cometabolism as a factor in microbial degradation of cycloparaffinic hydrocarbons. Archiv für Mikrobiologie 91, 87-90.

Claus, D. \& WaLKer, N. (1964). The decomposition of toluene by soil bacteria. Journal of General Microbiology 36, 107-122.

DAVIS, J. B. \& RAYMOND, R. L. (I96I). Oxidation of alkyl-substituted cyclic hydrocarbons by a Nocardia during growth on $n$-alkanes. Applied Microbiology 9, 383-388.

Fredericks, K. M. (1966). Adaptation of bacteria from one type of hydrocarbon to another. Nature, London 209, 1047.

Gibson, D. T., Cardini, G. E., Maseles, F. C. \& Kallio, R. E. (1970). Incorporation of oxygen-i 8 into benzene by Pseudomonas putida. Biochemistry 9, I63I-I635.

Gibson, D. T., Hensley, M., Yoshioka, H. \& Mabry, T. J. (1970). Formation of (+)-cis-2,3-dihydroxy-Imethylcyclohexa-4,6-diene from toluene by Pseudomonas putida. Biochemistry 9, 1626-1630.

Gibson, D. T., Koch, J. R. \& KalLIO, R. E. (I968). Oxidative degradation of aromatic hydrocarbons by microorganisms. I. Enzymatic formation of catechol from benzene. Biochemistry 7, 2653-266I.

JoNes, J. G. \& EDINGTON, M. A. (I968). An ecological survey of hydrocarbon-oxidising micro-organisms. Journal of General Microbiology 52, 38I-390.

KitagaWa, M. (1956). Studies on the oxidation mechanism of the methyl group. Journal of Biochemistry 43, $553-563$.

MANFREDI, R. \& WANG, D. I. C. (1972). Simple method for determining cell and hydrocarbon concentration during fermentation. Biotechnology and Bioengineering 14, 267-27I.

Norris, D. B. \& Trudgill, P. W. (1971). The metabolism of cyclohexanol by Nocardia globerula CLI. Biochemical Journal r2r, 363-370.

OoyAma, J. \& Foster, J. W. (I965). Bacterial oxidation of cycloparaffinic hydrocarbons. Antonie van Leeuwenhoek 3r, 45-65. 